\title{
INVESTMENT ANALYSIS OF A PIGLET PRODUCER FARM - A HUNGARIAN CASE STUDY
}

\author{
István Szúcs, László Szántó, László Szólloósi \\ University of Debrecen Faculty of Economics and Business Institute of Applied Economics Sciences
}

\author{
szucs.istvan@econ.unideb.hu \\ szantoo.laszlo@gmail.com \\ szollosi.laszlo@econ.unideb.hu
}

\begin{abstract}
The pig population in Hungary was about 8 million in 1990, while this number dropped to only 2.8 million by 2018. The previously so successful integrated domestic pig farming has almost completely disappeared and most of the smaller farms still operating in the 1990s are no longer functioning. At present, a process of concentration can be observed, which was accompanied by the further specialization of pig farming. The main profile of most pig farms is fattening, but there is a smaller number of farms in Hungary today specialized for piglet production, the successful operation of which requires significantly more expertise and more complex technology.

The main aim of this study is to present the production and economic indicators of a pig farm specialized in piglet production in Hungary as a result of a greenfield investment in the current economic environment, on a case study basis. For this purpose, an economic simulation was prepared based on primary data collection, operating on a deterministic basis, modelling the production and economic processes of the farm. The performed calculation does not derive the economic indicators of the activity from accounting records, but assigns the prices of natural inputs used on the basis of technological data. Primary data and information collection (e.g. technological data, input and output prices, unit cost items, etc.) took place between 2018-2019.

At the purchase prices of pigs in the last two years, which have increased significantly due to the African Swine Fever (ASF), the majority of pig farms in Hungary have an outstanding profit-making capacity. The physical efficiency indicators of the analysed pig farm are almost identical to the average data of such farms in the Netherlands, which has one of the most developed pig industry. The income of the examined pig farm at farm level is about 734 thousand EUR, i.e. 232 EUR per sow. Moreover, this activity is profitable even without subsidies. As a result, the greenfield investment pays off in the 8th year by default (average scenario). The investment has a Net Present Value (NPVr=3\%) of EUR 2,609 thousand for 10 years, an Internal Rate of Return of $8.5 \%$, and a Profitability Index (PIr=3\%) of 1.3. At the same time, risk factors such as sales prices, output and capacity utilization, and feed costs should be taken into consideration as in extreme cases the return on investment may be unfavourable (pessimistic scenario).
\end{abstract}

Keywords: piglet production, farm level data, simulation model, cost-profit analysis, greenfield investment (JEL classification: D24, M11, Q12)

\section{INTRODUCTION}

Pork has played a prominent role in feeding humanity for thousands of years. Its production and consumption are intertwined with the development of the production culture of agriculture. Throughout history, it has been observed that the consumption of pork increased in parallel with the improvement of agricultural production. Pig farming is most affected by the development and production level of cereal production.

Pigs are amenable to many different styles of farming: intensive commercial units, commercial free range enterprises, or extensive farming. Historically, farm pigs were kept in small numbers and were closely associated with the residence of the owner, or in the same village or town (Ganaba et al., 2011). They were valued as a source of meat and fat, and for their ability to convert inedible food into meat, and were often fed household food waste when kept on a homestead. Pigs have been farmed to dispose of municipal garbage on a large scale. All these forms of pig farm are in use today, though intensive farms are by far the most popular, due to their potential to raise a large amount of pigs in a very costefficient manner (Yu and Abler, 2014; Barbour, 2014). In developed nations, commercial farms house thousands of pigs in climate-controlled buildings. Pigs are a popular form of livestock, with more than one billion pigs butchered each year 
worldwide, 100 million of them in the USA. The majority of pigs are used for human food but also supply skin, fat and other materials for use as clothing, ingredients for processed foods, cosmetics, and medical use (Anonymous, 2020).

In recent years, most Hungarian pig farms have struggled with profitability problems, and the cost of fattening pigs has been higher than the selling price in several cases, endangering the sustainability of the activity. The higher prime cost typical of the majority of producers in international comparison is mainly due to genetics, housing and feed technology, as well as economies of scale. In the Hungarian pig sector, technology is a key issue, as we lag significantly behind the developed European competitors in this respect. The available capacities are approximately 25 years old, i.e. most of them are obsolete. It is important to emphasize that the modernity of technology fundamentally influences production indicators and, as a consequence, the income generating capacity of the activity (Popp et al., 2015; Apáti and Szőllősi, 2018).

In addition, it is important to highlight the lack of specialization. Pork production basically consists of two wellseparable production processes, one is sow keeping and piglet rearing, the purpose of which is the production of raw material for fattening (piglets), and the other is the fattening of pigs, the end product of which is slaughter pigs. Despite the fact that these two processes can be performed most efficiently in farms specialized for the given purpose, sow keeping and fattening are mostly not separated in Hungary, as farms perform both activities at the same time (Apáti and Szôllôsi, 2018). It is already a positive thing if these two activities take place on separate farms within a given enterprise. Among the causes of efficiency problems, Kömúves and Horváthné Petrás (2017) also highlight that, in many cases, commodityproducing farms do not pay enough attention to breeding and piglet production by concentrating only on fattening. In their opinion, it is cheaper to use a self-produced gilt for breeding purposes than to buy it from a stock, or to keep a 4-5-year-old self-produced boar for production purposes (even if it does not have the most excellent genetic characteristics), than to obtain a new one from a controlled stock. This questionable farming practice is often reflected in the relatively poor reproductive and fattening rates.

In addition to the shortcomings in the production of raw materials, the problems in the manufacturing industry also make the situation of the supply chain more difficult. Of these problems, small farm size and the inadequate capacity utilization are of paramount importance in international comparison (Szőllősi et al., 2017).

The current global animal health problem today is the Porcine Reproductive and Respiratory Syndrome virus (PRRS) and the African Swine Fever (ASF), which led to significant changes in global pork trade and production. As a result, Hungarian producers are experiencing increased demand and, at the same time, rising purchase prices over the last 1-2 years. Due to rising sales prices, the profitability situation of Hungarian producers has significantly improved, but this market situation will not be maintained in the long run. Therefore, in this income situation, it would be important to invest in increasing efficiency and capacity. The authors of this paper share the standpoint of Popp et al. (2015), i.e. greenfield investments should be given priority in development decisions, since in the case of renovations, the design of farm buildings and their locations on the farm are given, therefore, is not possible to change them substantially. The current investment and interest subsidy system also provides favourable conditions for the establishment of new farms and the modernization of existing ones.

In connection with the above mentioned aspects, the aim of this study is to present the production and economic indicators of a Hungarian farm established as a result of greenfield investment and specialized exclusively in piglet production, in the form of a case study. For this reason, our hypothesis is that (H1) piglet production in Hungary is economically sustainable, i.e. profitable in the current economic environment, and (H2) as a consequence, return is realized on the greenfield investment during its useful life.

\section{LITERATURE REVIEW}

\section{Pork production}

The main product of pig fattening is basically slaughter pigs, which are sold to processors. An increasing number of European companies are also building their own slaughterhouse in the context of vertical integration and processing pork themselves to increase added value. In addition to the production of pigs for slaughter, many companies are also involved in the rearing of pigs for breeding / fattening for the purpose of selling them.

The total amount of meat produced in the world increased by 110 million tonnes from 225 to 335 million tonnes between 1998 and 2017. Of the different meat types, pork was produced in the largest quantities until 2016, but since then poultry has taken the lead. Between 1998 and 2017, pork production increased from 89 million tonnes to 120 million tonnes, which is a $35 \%$ increase. The total production of the five most significant pork producing economic units in the world (China, European Union, USA, Brazil and Vietnam) amounted to more than 100 million tons (81\%) in 2017. The top five pork producing countries of the EU-28 are Germany, Spain, France, Poland and Denmark (FAO, 2019). Global pork production is projected to grow by 2028 , but at a much slower pace than in previous years. This phenomenon is basically due to two main reasons: (1) the population of the more developed countries consider pork one of the so-called unhealthy meats in the spirit of health-conscious diet; therefore, pork is eliminated from their diet at an increasing frequency; (2) due to changes in EU environmental policy, production is expected to decline owing to problems with manure disposal (Balogh, 2017; OECD-FAO, 2019). According to some forecasts, EU meat production will continue to grow in the future, driven mainly by the ASF epidemic in Asia, unless this virus appears or causes an epidemic in European countries (EC, 2019c; EC, 2019d).

In Hungary, pig breeding has played a decisive role in the past. Examining the data of HCSO (2020), it can be stated that 
the Hungarian pig population reached its maximum in 1983 (9.8 million pigs), and it has decreased to less than one third during the 30 years since then. About three-quarters (76\%) of pigs are owned by companies, and the role of individual farmers in pig farming is steadily declining. While in 2001 and 2002, the proportion of pigs on behalf of enterprises and individual farms was $50-50 \%$, today the proportion of individual farmers is only $24 \%$.

Figure 1. Changes in the number of pigs in Hungary (1999-2017)

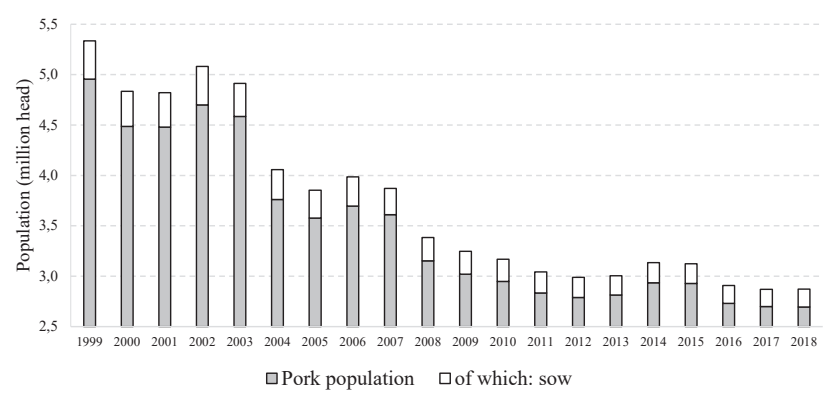

Source: Own compilation based on data of HCSO (2020)

Regarding the development of the number of pigs in Hungary (Figure 1), it can be stated that the number of pigs in 1999 (5.5 million) decreased by almost half, to 2.9 million by 2018 . The largest decrease was observed in 2004, Hungary's EU-accession. In this year, the Hungarian pig population decreased by 850,000 pigs (HCSO, 2020). To address the problems of the Hungarian pig sector, the Hungarian government introduced the "Pig Strategy" in 2012, in which it aimed to improve the competitive position of pig producers and increase the number of pigs in Hungary (i.e. to double the number of 3 million). Today, however, it can be concluded that this measure proved to be unsuccessful despite the significant capital loss, and it was not enough to boost the sector (Kőmúves and Horváthné Petrás, 2017). One of the main reasons for this outcome is that, due to the Russian embargo imposed in 2014, Russia has announced a ban on imports of all agricultural products from EU member states, including pork. As a result, significant quantities of pork have accumulated on the EU's internal market, leading to oversupply, which has led to a sharp fall in market prices (Boulanger et al., 2016; Smutka et al., 2016). The majority of Hungarian producers could not meet this price competition, resulting in a decrease in the stock again nationwide, as opposed to the increase in the number of pigs expected by the "Pig Strategy". However, it should be noted that the current favourable economic situation did not result in the targeted growth of the Hungarian pig population either.

\section{Pork consumption}

One of the basic elements of a healthy and balanced human diet is meat consumption (Horn, 2018). People's meat consumption habits differ depending on their financial, cultural and religious situation and personal approach. Pork is one of the most widely consumed meats in the world. In addition, the fact that it has a good feed conversion ratio, a relatively short fattening time and high fertility also played a significant role in the spread of pig farming (Vida and Szúcs, 2020). Ábel and Hegedősné (2015) mention that today's perception of pork - i.e. pork consumption is not healthy - will result in a further decline in demand in the future.

Pigs were originally bred to rapidly gain weight and back fat in the late 1980s. In the more fat-conscious modern days, pigs are now being bred to have less back fat and produce more offspring, which pushes the sow's body too far and is deemed one of the causes of the current prolapse epidemic (Berman, 2018).

Figure 2 shows the per capita consumption of pork, beef and poultry between 1998 and 2017 globally and in the Member States of the European Union. Globally, since 2008, poultry meat consumption has exceeded pork consumption. The latter has grown by $43 \%$ in twenty years. In contrast, there has been stagnation in pork consumption in the EU-28. The EC (2019a) predicts that EU per capita pork consumption will decrease by around 2 kilograms by 2030 due to changing consumer habits.

Figure 2. Global and EU meat consumption (1998-2017)

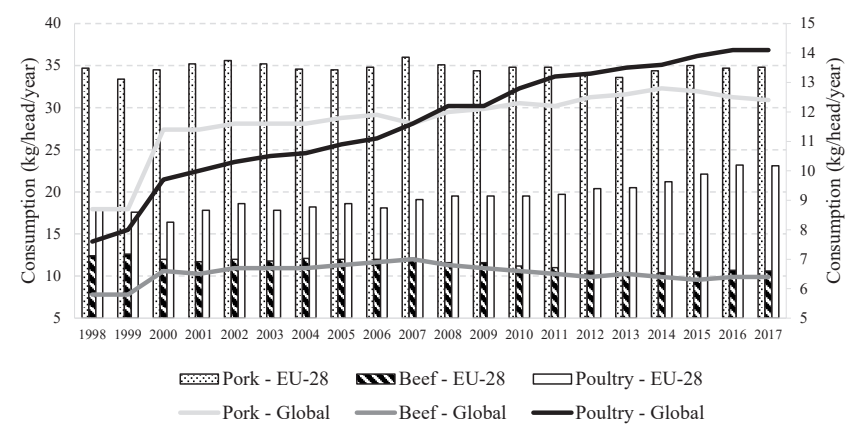

Source: Own compilation based on data of FAO (2019)

The yearly per capita meat consumption in Hungary was in the range of $55-70 \mathrm{~kg} /$ person/year in the last decade. As a result of the change in consumer habits, which is also supported by the results of Vida (2012), by the early 2000s, poultry meat consumption increased significantly, exceeding that of pork consumption. The consumption of the two types of meat has been almost the same since 2009 (25-30 kg/person/ year), accounting for almost $90 \%$ of the total domestic meat consumption together (HCSO, 2020). More expensive types of meat, such as beef, goose, lamb, are consumed in much smaller quantities in Hungarian households, which was also confirmed by several previous studies (Szakály, 2009; Popp et al., 2010; Vida, 2013; Jasák et al., 2014).

The yearly per capita meat consumption in Hungary was in the range of $55-70 \mathrm{~kg} /$ person/year in the last decade. As a result of the change in consumer habits, which is also supported by the results of Vida (2012), by the early 2000s, poultry meat consumption increased significantly, exceeding that of pork consumption. The consumption of the two types of meat has been almost the same since 2009 (25-30 kg/person/ year), accounting for almost $90 \%$ of the total domestic meat consumption together (HCSO, 2020). More expensive types of meat, such as beef, goose, lamb, are consumed in much 
smaller quantities in Hungarian households, which was also confirmed by several previous studies (Szakály, 2009; Popp et al., 2010; Vida, 2013; Jasák et al., 2014).

\section{Trade conditions of pork}

Pigs are farmed in many countries, although the main consuming countries are in Asia, i.e., there is a significant international and even intercontinental trade in live and slaughtered pigs. Despite having the world's largest herd, China is a net importer of pigs, and has been increasing its imports during its economic development. The largest exporters of pigs are the United States, the European Union, and Canada (Yu and Abler, 2014; FAO, 2019).

As regards the global import and export volumes in pork, there has been a sustained increase in the long term. The increase in export volumes is mainly due to Brazil and the European Union, the main reason being the increase in demand in China generated by ASF. Demand for both live and processed products is increasing in China (USDA, 2020). It is projected that by $2028,16 \%$ of global meat imports will come from pork. In 2018, 33.6 thousand tons of pork was imported into the EU. The largest quantities - 25.8 thousand tons - came from Norway, Switzerland and Serbia. The EU-28 member states exported nearly 3,870,000 tons of pork to the rest of the world in 2018. 55\% of the exported volume went to three countries: China (1,354 thousand tons, 35\%), Japan (433 thousand tons, 11.2\%) and South Korea (335 thousand tons, 8.7\%) (EC, 2019b).

Figure 3. Volume and value of the import and export of live pigs in Hungary (2004-2018)

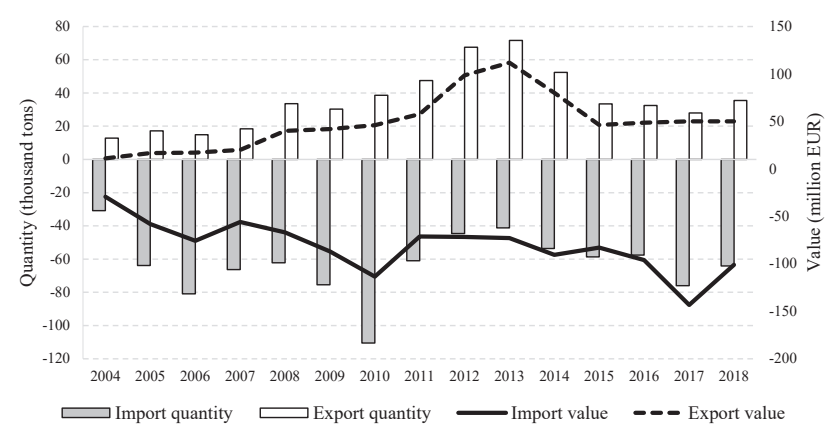

\section{Source: Own compilation based on data of RIAE PIS (2020)}

From Hungary's EU-accession in 2004 until 2010, the value of imported pork increased year by year from EUR 29.3 million to EUR 113.5 million. From 2013 onwards, there was another increase. In the period under review (20042018) (Figure 3), Hungarian pig exports (value and quantity) exceeded imports in only one three-year period, between 2011 and 2013. Kürthy et al. (2016) show that imported pigs, even with transportation costs, are cheaper than animals intended for sale by domestic producers.
Table 1. Volume and value of the import and export of live pigs in Hungary (2004-2018)

\begin{tabular}{lcccccc}
\hline & \multicolumn{3}{c}{ Quantity (tons) } & \multicolumn{3}{c}{ Value (thousand EUR) } \\
\cline { 2 - 7 } Years & Import & Export & $\begin{array}{c}\text { Export/ } \\
\text { Import }\end{array}$ & Import & Export & $\begin{array}{r}\text { Export/ } \\
\text { Import }\end{array}$ \\
\hline 2004 & 60000 & 81004 & 1.35 & 76919 & 142914 & 1.86 \\
2005 & 90221 & 84201 & 0.93 & 117860 & 153427 & 1.30 \\
2006 & 73679 & 86943 & 1.18 & 100878 & 174028 & 1.73 \\
2007 & 69743 & 95471 & 1.37 & 86947 & 171933 & 1.98 \\
2008 & 88662 & 102296 & 1.15 & 123968 & 187201 & 1.51 \\
2009 & 101992 & 111630 & 1.09 & 151003 & 209567 & 1,39 \\
2010 & 124847 & 165448 & 1.33 & 177577 & 295663 & 1.66 \\
2011 & 143144 & 161026 & 1.12 & 234996 & 307215 & 1.31 \\
2012 & 149363 & 143373 & 0.96 & 295410 & 303894 & 1.03 \\
2013 & 138097 & 140446 & 1.02 & 257579 & 294535 & 1.14 \\
2014 & 131072 & 139094 & 1.06 & 241615 & 317083 & 1.31 \\
2015 & 124167 & 143923 & 1.16 & 212909 & 309485 & 1.45 \\
2016 & 144246 & 137059 & 0.95 & 268171 & 317910 & 1.19 \\
2017 & 152098 & 141765 & 0.93 & 307365 & 344202 & 1.12 \\
2018 & 171668 & 133511 & 0.78 & 310401 & 280468 & 0.90 \\
\hline
\end{tabular}

${ }^{1}$ The data have been converted on the basis of the average HUF/EUR middle exchange rate in 2018 (318.92 HUF/EUR).

Source: Own compilation based on data of RIAE PIS (2020)

In addition to live pigs, pork (carcass, etc.) also plays a significant role in Hungarian foreign trade. This situation is more favourable for Hungary in terms of balance, as the volume of exports exceeds the volume of imports in several years. In the case of ratios of values, the situation is even more favourable, as the value of pork imports exceeded the value of exports only in 2018 (Table 1).

\section{Main physical efficiency indicators of pork production}

The average physical efficiency indicators of the main porkproducing countries in the world show significant differences and it needs to be emphasized that countries playing an important role in international trade do not always have the best indicators, as shown in the case of Brazil (Table 2). As regards weaning piglets, Denmark (33.3 pigs/sow/year) and the Netherlands (30.3 piglets/sow/year) perform best, while Hungary (25.5 piglets/sow/year) and Italy (24.8 piglets/sow/ year) show the weakest performance. There is also a $20-35 \%$ difference between the extreme values, i.e. Hungarian and Italian producers are at a significant competitive disadvantage already at the moment of calving compared to the producers of developed - mostly Western European - nations. In terms of specific feed consumption, Belgium and the Netherlands perform best, with figures of $2.6 \mathrm{~kg} / \mathrm{kg}$, while Sweden and Hungary have values of $3.06-3.07 \mathrm{~kg} / \mathrm{kg}$. Also, in terms of average body weight gain, Hungarian (753 g/day) and Spanish producers (715 g/day) are lagging behind the most. Finland has the worst farrowing rate, with an average of 164 days between two farrows. This is only 2 days shorter in Hungary. 
In contrast, the US (2.44 litters/sow/year, 150 days) and Brazil (2.41 litters/sow/year, 151 days) have outstandingly good values. Accordingly, it should also be said that piglets and fattening pigs also have the highest mortality rates in the US (4.20 and 4.64\%, respectively). Belgium and Italy have similarly weak indicators. However, as regards pig mortality, Hungarian producers show the best rate $(1.9 \%)$, while in the field of pig fattening, only 1.6 out of 100 animals die in Sweden. Hungarian pig farmers also have the weakest labour efficiency (27.1 hours/sow/year in sow keeping and 1.16 hours/pig/year in fattening). Accordingly, it can be seen that Hungary is among the last countries in terms of most physical efficiency indicators as Hungarian producers are not even able to come close to the European Union averages in the case of several indicators.

Table 2. Main production indicators of pig farming countries (2017)

\begin{tabular}{|c|c|c|c|c|c|c|c|c|}
\hline Country & 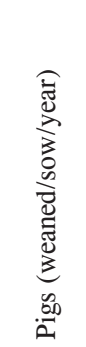 & 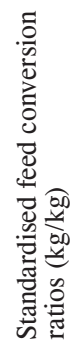 & 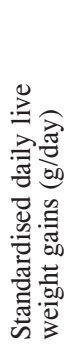 & 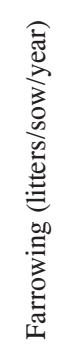 & 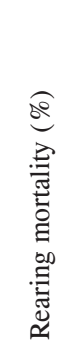 & 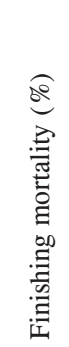 & 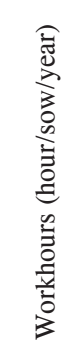 & 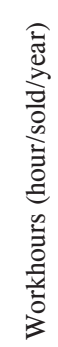 \\
\hline Austria & 24.90 & 2.75 & 825 & 2.29 & 3.00 & 1.81 & 15.30 & 0.35 \\
\hline Belgium & 29.80 & 2.60 & 767 & 2.34 & 4.00 & 3.10 & 10.67 & 0.30 \\
\hline Brazil & 27.40 & 2.81 & 821 & 2.41 & 2.00 & 2.20 & 11.04 & 0.36 \\
\hline Denmark & 33.30 & 2.82 & 930 & 2.28 & 2.28 & 3.10 & 25.03 & 0.18 \\
\hline Finland & 27.10 & 2.84 & 928 & 2.23 & 2.23 & 2.30 & 13.10 & 0.36 \\
\hline France & 28.20 & 2.71 & 815 & 2.37 & 2.79 & 3.63 & 12.55 & 0.15 \\
\hline Germany & 29.70 & 2.77 & 842 & 2.33 & 3.10 & 2.70 & 12.00 & 0.32 \\
\hline $\begin{array}{l}\text { Great } \\
\text { Britain }\end{array}$ & 25.80 & 2.94 & 805 & 2.29 & 3.78 & 2.79 & $\begin{array}{c}\text { no } \\
\text { data }\end{array}$ & $\begin{array}{c}\text { no } \\
\text { data }\end{array}$ \\
\hline Hungary & 25.50 & 3.07 & 753 & 2.25 & 1.90 & 3.96 & 27.10 & 1.16 \\
\hline Ireland & 28.50 & 2.82 & 811 & 2.36 & 2.91 & 2.21 & 15.00 & 0.28 \\
\hline Italy & 24.80 & 3.04 & 803 & 2.25 & 4.13 & 2.50 & $\begin{array}{c}\text { no } \\
\text { data }\end{array}$ & $\begin{array}{c}\text { no } \\
\text { data }\end{array}$ \\
\hline Netherlands & 30.30 & 2.58 & 845 & 2.36 & 2.50 & 2.40 & 7.45 & 0.26 \\
\hline Spain & 27.00 & 2.76 & 715 & 2.31 & 3.69 & 3.56 & 9.05 & 0.22 \\
\hline Sweden & 26.60 & 3.06 & 883 & 2.24 & 2.00 & 1.60 & 12.50 & 0.20 \\
\hline USA & 26.40 & 2.84 & 847 & 2.44 & 4.20 & 4.64 & 10.20 & 0.14 \\
\hline EU average & 27.80 & 2.83 & 826 & 2.30 & 3.02 & 2.78 & 13.92 & 0.33 \\
\hline
\end{tabular}

Source: AHDB (2018)

\section{Price level of main feeds used in the Hungarian pig sector}

In Hungarian pig farms, material costs make up a significant part of the annual production cost, of which feed costs account for the largest share. In fattening, mostly feed mixtures are used whose main components are cereals (wheat, maize, barley, triticale) and soybean (Szúcs, 2013). For all these reasons, the actual feed prices fundamentally determine the income situation of the pig sector. The price of feed cannot be influenced by the producer, but how much feed is used depends on the breed / genetics, the farm technology, the recipe, the animal health status and weather (e.g. animals eat less in high heat, resulting in less weight gain). Producers can influence some of these factors, including the average (specific) feed consumption in a given pig fattening farm. Figure 4 shows the average annual producer prices of the most important feeds and feed ingredients in Hungary.

The Hungarian cereal and feed market is basically price following, i.e. it is mainly influenced by European wholesale prices and market events. In the analysed period of 2010-2019, the prices of feed types ranged between 80150 EUR per tonne, while those of fattening feeds ranged between 175-295 EUR.

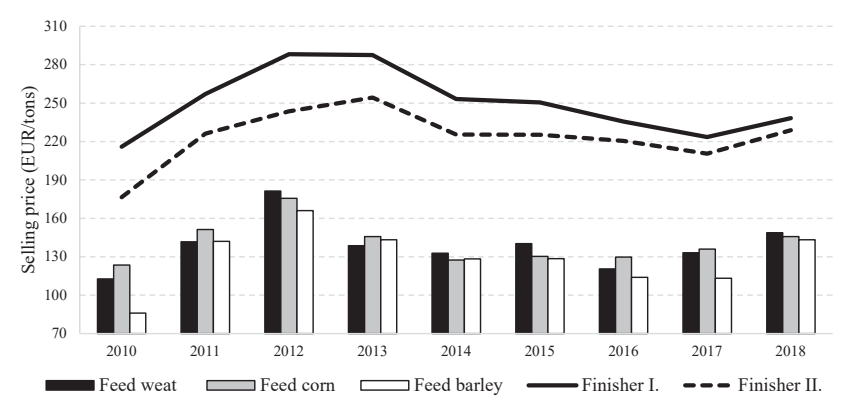

Figure 4. Trends of producer prices of main feed raw materials and annual sales prices of feed for fattening pigs in Hungary (2010-2018)

Note: The data have been converted on the basis of the average HUF/EUR middle exchange rate in 2018 (318.92 HUF/ EUR).

Source: Own compilation based on data of RIAE PIS (2020)

\section{Output prices of the Hungarian pig sector}

The Hungarian pig market, similarly to the feed market, is also price-following, i.e. it is mainly influenced by European wholesale prices and global market events. It is more profitable for an increasing number of Hungarian meat processors to obtain the raw material from abroad, because it is often cheaper, even with transport, than from domestic sources. Purchase prices in Hungary are basically determined by the value of German prices adjusted for logistics costs (transport / loading Germany => Hungary) (Marczin et al., 2020). Table 3 shows the prices of Hungarian-produced and imported slaughter pigs between 2010 and 2019. Compared to imports, pork prices in Hungary were 1-6\% higher in all years. 
Table 3. Slaughterhouse prices of domestic and imported pigs for slaughter (warm carcass weight) (2010-2019)

\begin{tabular}{lcccccccccc}
\hline Denomination & 2010 & 2011 & 2012 & 2013 & 2014 & 2015 & 2016 & 2017 & 2018 & 2019 \\
Hungarian (EUR/kg) & 1.13 & 1.26 & 1.48 & 1.55 & 1.51 & 1.34 & 1.42 & 1.58 & 1.41 & 1.73 \\
Import (EUR/kg) & 1.10 & 1.20 & 1.43 & 1.48 & 1.50 & 1.31 & 1.40 & 1.56 & 1.39 & 1.71 \\
Hungarian - Import (EUR) & 0.03 & 0.07 & 0.06 & 0.07 & 0.01 & 0.04 & 0.02 & 0.02 & 0.03 & 0.02 \\
Hungarian / Import (\%) & 103 & 106 & 104 & 105 & 101 & 103 & 102 & 101 & 102 & 101 \\
\hline
\end{tabular}

Source: Own compilation based on data of RIAE PIS (2020) and RIAE MPIS (2020)

Prices of Hungarian live pigs follow the development of German and Dutch market prices with a small lag in time (Figure 5.). There is a strong stochastic relationship between Dutch-Hungarian and German-Hungarian purchase prices (96\%), and the r-value and the adjusted R2 explain $92 \%$ of the output variables to justify the explanatory variables.

Figure 5. Weekly purchase prices of live pigs (2018-2019)

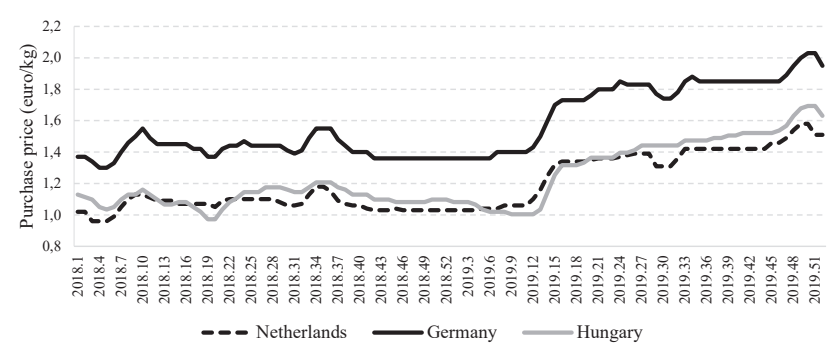

Note: The data have been converted on the basis of the average HUF/EUR middle exchange rate in 2018 (318.92 HUF/EUR).

Source: Own compilation based on data of Hunland (2020)

\section{Main competitive disadvantages of the Hungarian pig sector}

In recent years, several experts analysed the competitive disadvantages of the Hungarian pig sector. Among other things, the following reasons were highlighted: production on an inadequate scale; low level of willingness to invest; inadequate proportion of own or purchased feed; changes in consumer needs; inappropriate manure management; and the presence of ASF in feral pigs.

According to Balogh et al. (2009) and Csörnyei (2015), it is the inadequate farm size, i.e. the operation below the economies of scale of production, that generates a significant competitive disadvantage in the case of pig farms in Hungary. In our opinion, the utilization of production capacities is also an important factor for competitive pork production, as the fixed costs per product unit can be reduced as a function of increasing capacity utilization. Average variable costs at such production sizes do not depend on the utilization of production capacities. In addition, since the average total cost (ATC) is made up of two items, i.e. average variable cost (AVC) and average fixed cost (AFC), one of the most effective ways to reduce the average total cost (ceteris paribus) is to improve the utilization of production capacity in the pig sector.

In addition, in terms of husbandry technology, Hungarian producers lag behind their competitors the most. The tangible assets of Hungarian pig farmers are 25 years old on average (Apáti and Szőllósi, 2018). Older technology requires higher live labour costs, resulting in additional extra costs at the farm level.
Placing the amount of slurry produced during production is a problem even for farms with larger land areas. Use for energy purposes would require a significant additional investment, for which still only few are open in Hungary (Csörnyei, 2015).

According to the authors' summarizing opinion, there are very few modern, European-standard farms in pork production in Hungary. The areas in which Hungarian farms lag behind are genetics, housing technology, economies of scale, and feeding problems. Most of the available capacities are obsolete and their modernization is timely. Technology (housing, feeding and reproduction) is a key issue as it lags far behind advanced European competitors. State-of-the-art technologies significantly reduce specific feed consumption and mortality, but in turn increase daily weight gain and improve overall profitability. The financing of greenfield investments must be given priority, because in the case of renovations, the design, layout and microbial background of the buildings are given, i.e. it is not possible to change them significantly. One way to reduce feed costs is to utilize byproducts in pig fattening. At the same time, in Hungary, the inclusion of food and other industrial by-products (e.g. malt sprouts, DDGS, by-product of ethanol production, milling byproduct, sunflower meal, rapeseed meal) in the feed system lags behind the EU competitors.

\section{MATERIALS AND METHODS}

Primary and secondary data were also used in the preparation of the study. Secondary data come from various international and Hungarian databases (FAO, OECD-FAO, USDA, EC, AHDB, HCSO, RIAE MPIS, RIAE PIS) and technical literature. The primary data collection required for the study took place between 2018 and 2019 at the piglet producing farm of a Hungarian pig farming company. The data collected include production and technology data, input and output prices, and unit cost items. From the data collected at the company, we modelled the production and economic processes of the farm. Accordingly, we performed a deterministic simulation model calculation, similarly to the one created by Cehla et al. (2011), Szőllősi and Szúcs (2014) and Szőllősi et al. (2020). The calculation does not derive the cost-income relations of the activity from the analytical records and accounting data, but assigns prices to the inputs used on the basis of the technological data.

Based on the calculated cost-income data of the farm, we also examined the return on the greenfield investment. Accordingly, we used dynamic investment-economic indicators (NPV, IRR, DPP, PI). Subsequently, we conducted 
a sensitivity analysis examining the impact of the extreme (pessimistic and optimistic) states of the most determining factors on economic indicators.

The financial data are presented in EUR, and the middle exchange rate of the Hungarian National Bank in 2018 (318.92 HUF/EUR) was used to convert the data calculated in HUF (HNB, 2019).

The case study nature of the study should be emphasized, the obtained results should be evaluated accordingly and their generalizability is limited.

\section{RESULTS AND DISCUSSION}

\section{Cost-income relations of the analysed pig farm}

In this chapter, we present the cost-income relations of a pig farm specialized producing breeding stock in Hungary as a result of a greenfield investment, as well as the volume and rate of return on the investment, based on the company's past data, as a case study. The pig farm was built on the basis of a Dutch technology. The $16,500 \mathrm{~m} 2$ complex contains 850 farrowing pens capable of producing 90,000 piglets per year. Breeding is carried out from within the farm and no animals are transported to the farm since its establishment. Pigs are registered according to five age groups, of which the main products are suckling piglets (7.5 kg, 27-day-old), weaned piglets ( $23 \mathrm{~kg}, 65$-day-old) and gilts (125 kg, 175-day-old pigs).

Table 4 compares the main production indicators of the examined farm with the Hungarian, Dutch and EU averages. The farm performs at the same level as the average values in the Netherlands, which is a market leader in terms of weaned piglets ( 25.5 weaned/sow/year), FCR $(2.6 \mathrm{~kg} / \mathrm{kg})$, daily weight gain $(865 \mathrm{~g} /$ day) and working hours per sow (9.1 hours/sow/year). In terms of the mortality of piglets (1.9\%) and fattening pigs (3.7\%), the farm performs at the same level as the Hungarian average. In terms of the efficiency of working time, an outstandingly favourable value can be observed, resulted by the application of modern, automated technology.

Table 4. Comparison of key physical efficiency indicators

\begin{tabular}{|c|c|c|c|c|c|c|c|}
\hline D & 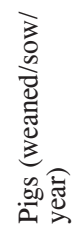 & 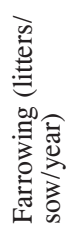 & 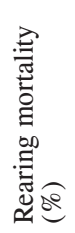 & 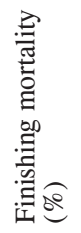 & 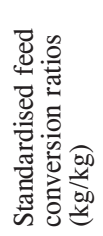 & 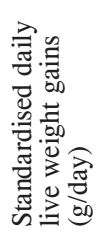 & 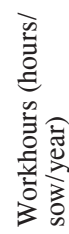 \\
\hline Analys & 29.9 & 2.3 & 1.9 & 3.7 & 2.6 & 865 & 9.1 \\
\hline $\mathrm{H}$ & 25.5 & 2.3 & 1.9 & 4.0 & 3.1 & 753 & 27.1 \\
\hline $\mathrm{Tl}$ & 30.3 & 2.4 & 2.5 & 2.4 & 2.6 & 845 & $t_{0}$ \\
\hline EU average & 27.8 & 2.3 & 3.0 & 2.8 & 2.8 & 826 & 13.9 \\
\hline
\end{tabular}

Source: AHDB (2018) and own data collection and calculation

The farm produces about 1,896 tonnes of live weight per year, of which more than $91 \%$ (1,725 tonnes) is sold as a main product. Table 5 shows the main economic indicators of the pig farm. The production value at farm level is 4,470 thousand EUR and 1,411 EUR per sow. This value is about $60 \%$ higher than the average production value (878 EUR/sow) of the dominant commodity-producing farms calculated for 2016 on the basis of pilot farm data of the Research Institute of Agricultural Economics (RIAE) (Szili and Szlovák, 2018), $91 \%$ of which is realized by the farm from revenues and $9 \%$ from subsidies.

The cost of production is 3,736 thousand EUR, of which 3,459 thousand EUR (93\%) is direct costs and 277 thousand EUR (7\%) is overheads. The production cost per sow is 1,179 EUR, which is $33 \%$ higher than the average production cost of the dominant commodity-producing farms calculated for 2016 on the basis of RIAE pilot farm sector data (EUR 891 / sow) (Szili and Szlovák, 2018). 74\% of direct costs are material costs, $8 \%$ are personnel costs, $17 \%$ are depreciation and $1 \%$ are other direct costs. Among the cost items, feed is the most significant, as the cost of feeding accounts for $50 \%$ of the total cost.

Table 5. Main economic indicators of the analysed pig farm

\begin{tabular}{|c|c|c|c|c|}
\hline \multicolumn{2}{|c|}{ Denomination } & \multirow{2}{*}{$\begin{array}{c}\begin{array}{c}\text { Value } \\
\text { (EUR) }\end{array} \\
4059764\end{array}$} & \multirow{2}{*}{$\begin{array}{c}\text { Value per sow } \\
\text { (EUR/sow) }\end{array}$} & \multirow{2}{*}{$\begin{array}{c}\begin{array}{c}\text { Value by live } \\
\text { weight } \\
\text { (EUR/100 kg) }\end{array} \\
214.1\end{array}$} \\
\hline 1. & Revenue & & & \\
\hline 2. & Subsidies & 410573 & 130 & 21.7 \\
\hline 3. & $\begin{array}{l}\text { Production value } \\
\qquad(1+2)\end{array}$ & 4470337 & 1411 & 235.8 \\
\hline 4. & Material cost & 2557117 & 813 & 134.9 \\
\hline 5. & Labour cost & 291255 & 184 & 15.4 \\
\hline 6. & Depreciation & 565628 & 179 & 29.8 \\
\hline 7. & Other direct cost & 45187 & 72 & 2.4 \\
\hline 8. & $\begin{array}{l}\text { Total direct cost } \\
\qquad(\Sigma 4-7)\end{array}$ & 3459187 & 1248 & 182.4 \\
\hline 9. & Gross margin (3-8) & 1011151 & 163 & 53.3 \\
\hline 10. & Overheads & 276735 & 87 & 14.6 \\
\hline 11. & $\begin{array}{l}\text { Total production cost } \\
\qquad(8+10)\end{array}$ & 3735922 & 1179 & 197.0 \\
\hline 12. & Income (3-11) & 734415 & 232 & 38.8 \\
\hline 13. & $\begin{array}{l}\text { Income without } \\
\text { subsidies (12-2) }\end{array}$ & 323842 & 132 & 17.1 \\
\hline 14. & $\begin{array}{c}\text { Cost-related } \\
\text { profitability (\%) }\end{array}$ & & 19.7 & \\
\hline
\end{tabular}

Source: own data collection and calculation

The farm, which specializes in piglet production, produces and sells three main products (suckling piglet and weaned piglet for fattening, and gilt for breeding), therefore, we determined the direct cost for all three products. Accordingly, we applied process costing with equivalent units, and we used the feed cost of each age group as the projection basis. The cost of a suckling piglet is 333 EUR / $100 \mathrm{~kg}$, while that of a weaned piglet is $107 \mathrm{EUR} / 100 \mathrm{~kg}$, and the cost of a gilt is $205 \mathrm{EUR} / 100 \mathrm{~kg}$.

Knowing the production value and the production cost, it can be stated that the examined farm specializing in the supply of fattening pigs continues to produce profitably. The cost-related profitability of the activity is $19.7 \%$, which is significantly higher than usual in the sector. At the farm level, the sectoral result is 735 thousand EUR, which remains 
positive even without subsidies (324 EUR). The income per sow is $232 \mathrm{EUR}$, compared to the national average (average sectoral result of the dominant commodity-producing farms calculated on the basis of RIAE pilot farm sector data (Szili and Szlovák, 2018), which showed a loss of 11.2 EUR per sow in 2016.

\section{RETURN ON GREENFIELD INVESTMENT}

The farm housing 3,100-3,200 sows which is presented in the study was established in recent years as part of a greenfield investment. The total cost of the investment was 8.5 million EUR, which included the purchase of the property from design to commissioning, public works, buildings, technological equipment and the initial sow population. The investment cost per sow is 2,650-2,750 EUR. The investment was financed by the company from $20 \%$ of its own resources, $37 \%$ of a subsidy and $43 \%$ of an investment loan. The investment loan is a longterm fixed loan with an interest rate of $1.5 \%$. Accordingly, the funding can be considered very favourable in this respect.

The investment economic analysis was performed for a period of 10 years. The yield of the alternative investment option was set at a calculated discount rate of $3 \%$ (opportunity cost), which is the average yield of the 10-year government securities of the Hungarian National Bank between 2016 and 2019 (HNB, 2020). When planning the cash flows for the future, we started from the current cost-income data, and also took into account the planned changes in the price level. We expected a $3 \%$ increase in the price level of sales and feed costs, $10 \%$ increase in personnel costs and 2-2\% increase of other direct costs. We also took into account the effect of the corporate tax shield, which is $9 \%$ in Hungary.

According to our calculations, the Net Present Value (NPV) of the investment is 2,609 thousand EUR at the end of the 10th year after the investment and return is realized in the 8th year (Discounted Payback Period, DPP). The Internal Rate of Return (IRR) is $8.5 \%$, which is $5.5 \%$ higher than the opportunity cost. The Profitability Index (PI) is 1.3. Altogether, it can be concluded that, although such investments have a significant capital requirement, a return on investment can be realized as a result of more favourable production and economic indicators.

\section{Sensitivity test}

A sensitivity test was also conducted in connection with the performed calculations. In doing so, we assessed the impact of the extreme (pessimistic and optimistic) states of the most determining factors on economic indicators with a scenario analysis. Table 6 summarizes the values of these influencing factors (sales prices, sales volume as a function of capacity utilization and unit feed costs) in optimistic and pessimistic cases compared to the base case. The extreme values of the assessment were determined on the basis of the previous years' average data of the HCSO (2020) in the case of the change in sales prices, and, the PIS (2020b) in the case of the specific feed costs. When estimating the more favourable and less favourable values of the sold volume, we took into account the capacity of the pig farm and its level of utilization.
Table 6. Extreme values of factors involved in the study

\begin{tabular}{lccccc}
\hline Denomination & \multicolumn{2}{c}{$\begin{array}{c}\text { Pessimistic } \\
\text { scenario }\end{array}$} & $\begin{array}{c}\text { Basic } \\
\text { scenario }\end{array}$ & \multicolumn{2}{c}{ Optimistic scenario } \\
\hline Sales prices & EUR/kg & $\begin{array}{c}\text { Dif. } \\
(\%)\end{array}$ & EUR/kg & $\begin{array}{c}\text { Dif. } \\
(\%)\end{array}$ & EUR/kg \\
weaned piglets & 2.23 & -10 & 2.48 & +5 & 2.72 \\
gilts & 1.16 & -10 & 1.29 & +5 & 1.41 \\
suckling piglets & 4.66 & -10 & 5.17 & +5 & 5.69 \\
Sold quantity & Tons & $\begin{array}{l}\text { Dif. } \\
\text { (\%) }\end{array}$ & Tons & $\begin{array}{l}\text { Dif. } \\
(\%)\end{array}$ & Tons \\
weaned piglets & 2.13 & -5 & 2.25 & +5 & 2.36 \\
gilts & 1.28 & -5 & 1.35 & +5 & 1.42 \\
suckling piglets & 0.92 & -5 & 0.97 & +5 & 1.01 \\
& EUR/ & Dif. & EUR/ & Dif. & EUR/ \\
Feed cost & produced kg & $(\%)$ & produced kg & $(\%)$ & produced kg \\
weaned piglets & 0.73 & -5 & 0.70 & +5 & 0.66 \\
gilts & 1.51 & -5 & 1.44 & +5 & 1.37 \\
suckling piglets & 1.83 & -5 & 1.74 & +5 & 1.82 \\
\hline
\end{tabular}

Source: own data collection and calculation

Table 7. Effect of extreme values of impact factors on key economic indicators

\begin{tabular}{lccc}
\hline Denomination & $\begin{array}{c}\text { Pessimistic } \\
\text { scenario }\end{array}$ & Basic scenario & $\begin{array}{c}\text { Optimistic } \\
\text { scenario }\end{array}$ \\
\hline $\begin{array}{l}\text { Income (EUR/sow) } \\
\mathrm{NPV}_{\mathrm{r}=3 \% ; \mathrm{t}=10 \text { years }}\end{array}$ & -79 & 232 & 425 \\
(thousand EUR) & -6349 & 2609 & 8029 \\
$\mathrm{IRR}_{\mathrm{t}=10 \text { years }}(\%)$ & -19.5 & 8.5 & 18.2 \\
$\mathrm{PI}_{\mathrm{r}=3 \% ; \mathrm{t}=10 \text { years }}$ & 0.3 & 1.3 & 1.9 \\
\hline
\end{tabular}

Source: own data collection and calculation

Table 7 summarizes the results of the scenario analysis. In the pessimistic and optimistic scenarios, all influencing factors included in the test are unfavourable and favourable at the same time, i.e. they show the most extreme conditions. In the worst case (pessimistic) scenario, the estimated annual income per sow is -79 EUR, which is $134 \%$ lower than the current values. In a more favourable case (optimistic scenario), this value can be $83 \%$ higher. No return is realized on the investment under pessimistic conditions, and the net present value is $-6,349$ thousand EUR. However, this condition assumes the extreme case in which each influencing factor has unfavourable values for 10 years. In contrast, under the most favourable conditions, even an internal rate of return of up to $18 \%$ can be expected. Examining the effect of each factor on the result separately, the sales prices of different age groups play the biggest role.

\section{CONCLUSIONS}

In this study, we presented the production and economic indicators of a pig farm specialized in piglet production in Hungary as a result of a greenfield investment, on a case study basis. Especially due to this case study nature, the generalizability of the results is limited. It can be stated that the pig farm, which was established as a result of the 
presented greenfield investment and specializes only in piglet production, can be characterized by very good production indicators (farrowing, number of weaned piglets, labour efficiency) in international comparison, and as a result has outstanding income-generating capacity. Accordingly, our hypothesis $\mathrm{H} 1$ is confirmed, that is "piglet production in Hungary is economically sustainable, i.e. profitable in the current economic environment".

The case study also confirmed that there is a very significant capital requirement for establishing relatively larger farms, that can also be considered modern at the international level, which we believe is essential for increasing efficiency in all areas of agriculture. In the case of the presented farm, as a result of the excellent production and economic indicators, the capital investment shows a favourable return, which is made even more favourable for businesses by the current support policy and funding environment. Accordingly, we accept our hypothesis $\mathrm{H} 2$, according to which "return is realized on the greenfield investment during its useful life". At the same time, attention is drawn to the role of risk factors, which can even adversely affect returns in extreme circumstances.

In our opinion, these favourable production and economic indicators are clearly based on, among other things, modern, automated buildings and technology. As a matter of course, these factors also require and are provided with proper genetics, nutrition and expertise. Our results and findings are in accordance with the findings of several other researchers (Nábrádi et al., 2009; Popp, 2014; Takácsné and Takács, 2016; Horn, 2018; Fountas et al., 2020; Kirkaya, 2020), according to whom improving the parameters of agricultural production (natural efficiency) is of key significance in increasing profitability and international competitiveness, as well as the improvement of environmental sustainability. In addition, these factors can be significantly improved through the complex application of advanced technologies, automation and digitization, as well as the required expertise.

\section{ACKNOWLEDGMENT}

This research was supported by the ÚNKP-20-1 New National Excellence Program of the Ministry for Innovation and Technology from the source of the National Research, Development and Innovation Fund.

\section{REFERENCES}

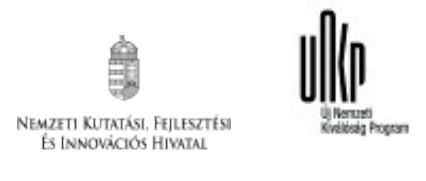

Ábel I., Hegedûsné Baranyai N. (2015): Sertéstartó gazdaságok eszközellátottságának vizsgálata különös tekintettel a beruházásokra / Examining the production equipment supply of pig farms with special regard to investments. Gazdálkodás. 59(6): 582-592.

AHDB (2018): 2017 Pig cost of production in selected countries. Warwickshire: Agriculture and Horticulture Development Board. https://pork.ahdb.org.uk/media/276369/costofpigproduction2017_181122_web.pdf, Approached Jan. 2020.
Anonymous (2020): Pig Farming. Wikipedia. https:// en.wikipedia.org/wiki/Pig_farming, Approached Jun. 2020.

Apáti F., Szőlloósi L. (2018): Főbb mezőgazdasági ágazatok gazdasági jelentôsége és üzemgazdasági kérdései / Economic significance and business issues of the major agricultural sectors. In: Üzemtan / Farm Business Management (ed.: Szúcs, I.). University of Debrecen, 214-291.

Balogh P. (2017): A sertéshústermelés globális és nemzetgazdasági jelentôsége / The global and national economic importance of pig production. Acta Agraria Debreceniensis. 73: 13-20.

Balogh P., Ertsey I., Fenyves V., Nagy L. (2009): Analysis and optimization regarding the activity of a Hungarian Pig Sales and Puchase Cooperation. Studies in Agricultural Economics. 109. 35-54. doi: 10.22004/ag.econ.49192

Barbour L. (2014): Where have all the pig farmers gone? https://www.abc.net.au/news/rural/2014-05-02/pig-farmer-decline/5426020, Approached Jun. 2020.

Berman R. (2018): On factory farms, the death rate of pig sows is soaring. https://bigthink.com/technology-innovation/pigdeaths-in-factory-farming-doubles?rebelltitem=1\#rebelltitem1, Approached Jun. 2020.

9Boulanger P., Dudu H., Ferrari E., Philippidis, G. (2016): Russian Roulette at the Trade Table: A Specific Factors CGE Analysis of an Agrinfood Import Ban. Journal of Agricultural Economics. 67(2): 272-291. doi: 10.1111/1477-9552.12156

Cehla B., Kovács S., Nábrádi A. (2011): Exploitation of relations among the players of the mutton product cycle. Apstract. 5(1-2): 129-134. doi: 0.22004/ag.econ.104652

Csörnyei Z. (2015): Hatékonyságot és innovációs készséget befolyásoló szempontok vizsgálata a magyar sertéstenyésztésben / Investigation of aspects influencing efficiency and innovation skills in Hungarian pig sector. Gazdálkodás. 59(2): 101-113. doi: 10.22004/ag.econ.208274

EC (2019a): EU Agricultural Outlook for markets and income 2019-2030. European Commission, DG Agriculture and Rural Development. https://ec.europa.eu/info/sites/info/files/foodfarming-fisheries/farming/documents/agricultural-outlook2019-report_en.pdf, Approached Jan. 2020.

EC (2019b): Pig Market Situation - CMO Committee 12 December 2019. European Commission, DG Agriculture and Rural Development. https://ec.europa.eu/info/sites/info/files/ food-farming-fisheries/farming/documents/pig-market-situation_en.pdf, Approached Jan. 2020.

EC (2019c): Short-term outlook for EU Agricultural Markets in 2018 and 2019. Spring 2019. European Commission, DG Agriculture and Rural Development. https://ec.europa.eu/info/sites/ 
info/files/food-farming-fisheries/farming/documents/shortterm-outlook-spring-2019_en.pdf, Approached Feb. 2020.

EC (2019d): Short-term outlook for EU Agricultural Markets in 2019 and 2020. Autumn 2019. European Commission, DG Agriculture and Rural Development. https://ec.europa.eu/info/sites/ info/files/food-farming-fisheries/farming/documents/short-termoutlook-autumn-2019_en.pdf, Approached Feb. 2020.

FAO (2019): Database. Food and Agriculture Organization of the United Nations. http://www.fao.org/faostat/en/\#data, Approached Dec. 2019.

Fountas S., Espejo-García B., Kasimati A., Mylonas N., Darra N. (2020): The future of digital agriculture: technologies and opportunities. IT Professional. January/February 2020. 24-28. doi: 0.1109/MITP.2019.2963412

Ganaba R., Praet N., Carabin H., Millogo A., Tarnagda Z., Dorny P., Hounton S., Sow A., Nitiéma P., Cowan LD. (2011). Factors Associated with the Prevalence of Circulating Antigens to Porcine Cysticercosis in Three Villages of Burkina Faso. PLoS Neglected Tropical Diseases. 5(1): e927. doi: 10.1371/ journal.pntd.0000927

HCSO (2020): Database. Hungarian Central Statistical Office. https://www.ksh.hu, Approached Jan. 2020.

HNB (2019): MNB Középárfolyam - 2018 évi áttekintő / MNB Central Exchange Rate - 2018 overview. Hungarian National Bank. http://mnbkozeparfolyam.hu/arfolyam-2018.html, Approached Feb. 2020.

HNB (2020): Referenciahozamok / Reference rate. Hungarian National Bank. https://www.akk.hu/hu/statisztika/hozamok-indexekforgalmi-adatok/referenciahozamok, Approached Jan. 2020.

Horn P. (2018): A mezőgazdasági termelés jövőjét meghatározó néhány fontos kérdéskör / Some important issues determining the future of agricultural production. Gazdálkodás. 62(5): 385405. doi: 10.22004/ag.econ. 279712

Hunland (2020): Our weekly pig prices. Hunland. https://www. hunland.com/trade/pig-prices, Approached Feb. 2020.

Jasák H., Fehér A., Szakály Z. (2014): Fogyasztói preferenciák és attitűdök hagyományos és tájjellegű élelmiszerekkel kapcsolatban / Consumer preferences and attitudes related to traditionala and regional foods. In: Marketing megújulás / Marketing renewal (ed.: Hetei E., Révész B.). Szeged: Universtiy of Szeged Facult of Economics. 2014. August 28-29. 372-381.

Kirkaya A. (2020): Smart farming-precision agriculture technologies and practices. Journal of Scientific Perspectives. 4(2): 123-136.

Kőmûves Zs., Horváthné Petrás V. (2017): A sertéshústermelést és -fogyasztást befolyásoló tényezők / Factors influencing pork production and consumption. Élelmiszer, Táplálkozás és Marketing. 13(1): 3-9. doi: 10.33567/etm.2253

Kürthy Gy. (ed.), Dudás Gy. (ed.), Felkai, BO., Bene A., Darvasné Ördög E., Garay R., Györe D., Radóczné Kocsis T., Székelyhidi K. (2016): A magyarországi élelmiszeripar helyzete és jövőképe / Situation and vision of the Hungarian food industry. Budapest: Research Institute of Agricultural Economics. 72. doi: 10.7896/at1603

Marczin T., Nagy L., Szenderák J., Balogh P. (2020): Árelemzés a magyarországi sertésintegrációban / Price Analysis to Demonstrate the Importance of the Hungarian Pork Integration. Gazdálkodás. 64(2): 117-132. doi: 10.22004/ag.econ.303791

Nábrádi A., Pető K., Balogh V., Szabó E., Bartha A., Kovács K. (2009): Efficiency indicators in different dimension. Apstract. 3(1-2): 7-23. doi: 10.22004/ag.econ.49127

OECD-FAO (2019): OECD-FAO Agricultural Outlook 20192028. Paris: OECD Publishing - Rome: Food and Agriculture Organization of the United Nations. http://www.fao.org/3/ ca4076en/ca4076en.pdf, Approached Jan. 2020.

Popp J. (2014): Hatékonyság és foglalkoztatás a magyar mezőgazdaságban / Efficiency and Employment in Hungarian Agriculture. Gazdálkodás. 58(2): 173-184. doi: 10.22004/ ag.econ. 201403

Popp J., Potori N., Papp G. (2010): A magyar tejvertikum diagnózisa / Diagnosis of the Hungarian Milk Sector. Gazdálkodás. 54(1): 81-91.

Popp J., Szakály Z., Pető K., Harangi-Rákos M. (2015): A sertéstenyésztés helyzete a globális kihívások tükrében / Pig farming and global challenges. Állattenyésztés és Takarmányozás. 64(3): 207-225.

RIAE MPIS (2020): Researsh Institute of Agricultural Economics Market Price Information System. https://pair.aki.gov. hu/web_public/general/home.do, Approached Feb. 2020.

RIAE PIS (2020): Researsh Institute of Agricultural Economics Pig Information System. https://sertesinfo.aki.gov.hu/, Approached Feb. 2020.

Smutka L., Spicka J., Ishchukova N., Selby R. (2016): Agrarian import ban and its impact on the Russian and European Union agrarian trade performance. Agricultural Economics - Chech. 62: 439-506. doi: 10.17221/294/2015-AGRICECON

Szakály Z. (2009): Egészségmagatartás és funkcionális élelmiszerek: Hogyan vélekednek a hazai fogyasztók? / Health behaviour and functional foods: What Hungarian consumers think of them? Élelmiszer, Táplálkozás és Marketing. 6(1-2): 9-18. 
Szili V., Szlovák S. (2018): A főbb mezőgazdasági ágazatok költség- és jövedelemhelyzete 2016 / The cost and income situation of the major Hungarian agricultural products in 2016. Budapest: Research Institute of Agricultural Economics. 26-28. doi: 10.7896/ai1803

Szőllôsi L., Molnár Sz., Ladányi K., Karnai L., Szű́cs I. (2017): Cost analysis of pig slaughtering: a Hungarian case study. Apstract. 11(3-4): 121-130. doi: 10.19041/APSTRACT/2017/3-4/17

Szőllôsi L., Molnár Sz., Szű́cs I., Erdős A. (2020): A tojástermelés jövedelemtermelő képességének alakulása alternatív tartásmódok (madárház/mélyalom) esetén / Profitability of the egg production in alternative housing systems (aviary/barn). Gazdálkodás. 64(3): 202-214. doi: 10.22004/ag.econ.303795

Szőllősi L., Szű́cs I. (2014): An economic approach to broiler production. A case study from Hungary. Annals of the Polish Association of Agricultural and Agribusiness Economists. 16(3): 275-281.

Szűcs I. (2013): A sertéságazat ökonómiai és szervezeti kérdései / Economic and organizational issues of the pig sector In: Vállalati és ágazati gazdaságtani ismeretek / Knowledge of corporate and sectoral economics (ed.: Apáti F.). Debrecen: University of Debrecen Centre of Agricultural and Management Science. 229-239.

Takácsné György K., Takács I. (2016): A magyar mezőgazdaság versenyképessége a hatékonyságváltozások tükrében / Competitiveness of Hungarian Agriculture in Connection with Change of Its Effectiveness. Gazdálkodás. 60(1): 31-50. doi: 10.22004/ ag.econ. 253871

USDA (2020): Livestock and Poultry: World Markets and Trade. January 10, 2020. U.S. Department of Agriculture. https://downloads.usda.library.cornell.edu/usda-esmis/ files/73666448x/sb397r25n/0z709c25b/livestock_poultry.pdf, Approached Jan. 2020.

Vida V. (2012): Consumer valuation and market situation of the pork sector in Hungary. $\mathrm{PhD}$ thesis. Debrecen: University of Debrecen, Károly Ihrig Doctoral School of Management and Business. 1-25.

Vida V. (2013): Consumer attitudes and preferences about the pork meat in Hungary (based on cluster analysis). Apstract. 7(45): 151-158. doi: 10.19041/Apstract/2013/4-5/21

Vida V., Szúcs I. (2020): Pork production and consumption issues from the perspective of the religion and the world's growing population. Apstract. 14(1-2): 119-126. doi: 10.19041/APSTRACT/20201-2/16

Yu X., Abler D. (2014): Where have all the pigs gone? Inconsistencies in pork statistics in China. China Economic Review. 30: 469-484. doi: 10.1016/j.chieco.2014.03.004 
